\title{
Увеличение
}

\section{пенсионного возраста: аргументы «за» и «против»}

И.В. ЩЕТИНИНА, доктор экономических наук, профессор ВАК, Институт экономики и организации промышленного производства СО РАН, Новосибирск. E-mail: irer@ngs.ru

В статье развенчиваются аргументы в пользу необходимости повышения пенсионного возраста. Анализ фактического социально-экономического положения населения России свидетельствует о неподготовленности страны к проведению реформы. Фактическая продолжительность жизни населения РФ не соответствует ожидаемой, как и продолжительности и уровню жизни населения развитых стран. Растет заболеваемость жителей многих регионов России. Уровень фактической оплаты труда и соответствующий международным требованиям потенциальный размер пенсий не ниже 40\% от заработной платы не позволяют обеспечить необходимое качество жизни. Продление пенсионного возраста не восполнит недостаток квалифицированных кадров в экономике. Необходимые затраты на проведение пенсионной реформы могут превысить полученную экономию бюджетных средств от повышения пенсионного возраста. Предлагается отсрочить вступление в силу принятого закона о пенсионной реформе и провести целенаправленную подготовительную работу в системе здравоохранения, пенсионного обеспечения, экономического регулирования цен и тарифов, по другим направлениям. Это позволит по мере готовности экономики и общества вернуться к рассмотрению вопроса о необходимости повышения пенсионного возраста.

Ключевые слова: численность населения; продолжительность жизни; смертность; трудоспособный и пенсионный возраст; безработные; занятость; доходы; пенсионная система

В современной России долго шла полемика о необходимости повышения пенсионного возраста, так как это затрагивает интересы практически каждой семьи. Все стороны казались убедительными в своих аргументах. В итоге 27 сентября 2018 г. Государственная дума Федерального собрания РФ приняла в третьем окончательном чтении законопроект о пенсионной реформе. Верхняя палата его одобрила, и 03.10.2018 Президент РФ В.В. Путин подписал ${ }^{1}$. Казалось бы, на этом надо поставить точку. И все же если более

\footnotetext{
${ }^{1}$ Федеральный закон от 3 октября 2018 г. № 350-Ф3 «О внесении изменений в отдельные законодательные акты Российской Федерации по вопросам назначения и выплаты пенсий» // Гарант. URL: http://www.garant.ru/files/4/2/1221724/1221724.rtf (дата обращения: 04.10.2018).
} 
пристально посмотреть на возможные последствия такого решения, провести непредвзятые исследования, в том числе с привлечением данных Росстата и других достоверных источников, возникают серьезные сомнения в необходимости повышения пенсионного возраста в стране.

Разберем по пунктам аргументы «за» ${ }^{2}$ и социально-экономические доказательства «против» этого шага по результатам проведенного анализа.

1. Аргумент «за»: действующчий пенсионный возраст 60 лет для мужчин и 55 лет для женщин-впервые был закреплен в 1928 г. и получил дальнейшее развитие с учетом характерных для советского периода особенностей труда и структуры занятости граждан, ожидаемой продолжительности жизни, трудовой активности. К настоящему времени продолжительность жизни россиян в целом значительно увеличилась.

\section{Результаты анализа}

Если проанализировать численность населения по возрастным группам, то утверждение об увеличении продолжительности жизни в России оказывается не совсем верным, поскольку официальный расчет этого показателя учитывает детскую смертность и вероятность лет дожития взрослого населения. Благодаря тому, что детская смертность существенно сократилась (в два раза за последние 10-12 лет) ${ }^{3}$, показатель средней продолжительности жизни действительно увеличился. Но продолжительность жизни взросльх при этом существенно не изменилась, и численность населения пожилого возраста значимо не выросла (рис. 1).

Если проследить динамику численности населения в возрасте 65-69 лет до возвращения Крыма, за счет которого в 2014 г. выросло общее количество населения РФ, то общая тенденция будет отрицательная.

В возрастной группе 70 лет и более (в том числе с учетом Крыма) с 2012 по 2016 гг. сокращение численности составило 9,9\% (с 14,4 до 13,1 млн чел.) (рис. 2).

\footnotetext{
2 Здесь и далее все аргументы «за» приведены из личной переписки автора статьи с руководством Минтруда России и аппаратом Правительства РФ в июле 2018 года. Аналогичные аргументы приведены в СМИ.

${ }^{3}$ Регионы России. Социально-экономические показатели. 2017: Стат. сб. / Росстат. M., 2017. C. 67.
} 


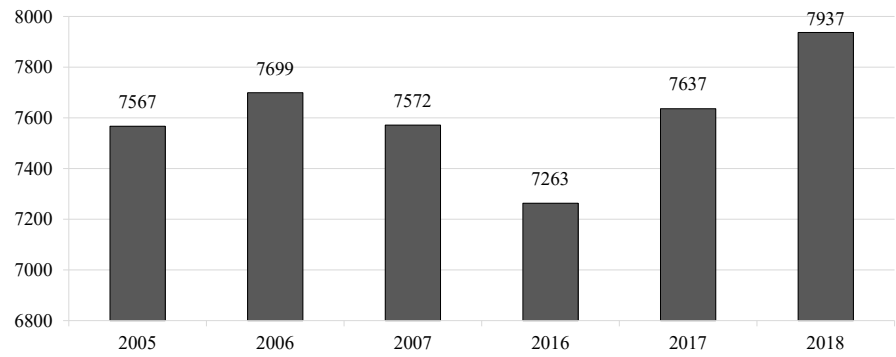

Puc. 1. Численность населения РФ в возрасте 65-69 лет ${ }^{4}$ (с учетом Крыма) в 2005-2018 гг., тыс. чел.

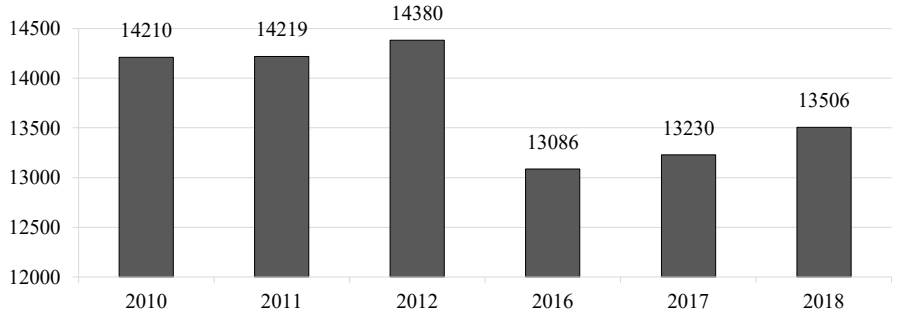

Pис. 2. Численность населения РФ в возрасте 70 лет и более (с учетом Крыма) в 2010-2018 гг., тыс. чел.

Высока смертность населения России и в трудоспособном возрасте. Только за 2016 г. этот показатель составил 436 тыс. человек. В 2017 г. в этой группе населения умерло почти 313 тыс., и за первую половину 2018 г. - 195 тыс. человек ${ }^{5}$. То есть сотни тысяч людей в России не доживают до пенсионного возраста.

Таким образом, статистически ожидаемая продолжительности жизни населения в среднем по стране существенно отличается от фактической.

\footnotetext{
${ }^{4}$ Составлено автором по данным: Демография // Официальная статистика. Население [Эл. pесурс] / Федеральная служба госстатистики. URL: http://www.gks.ru/wps/ wcm/connect/rosstat_main/rosstat/ru/statistics/population/demography/\# (дата обращения: 01.10.2018).

${ }^{5}$ Смертность населения в трудоспособном возрасте за январь-июнь $2017-$ 2018 гг. // Официальная статистика. Население / Демография [Эл. ресурс] / Федеральная служба Госстатистики. URL: http://www.gks.ru/free_doc/new_site/population/demo/ smert.htm (дата обращения: 01.10.2018).
} 
Кроме того, значительные различия в продолжительности жизни наблюдаются по регионам России (рис. 3), по месту жительства (город, село, отдаленное поселение) и т.д 6

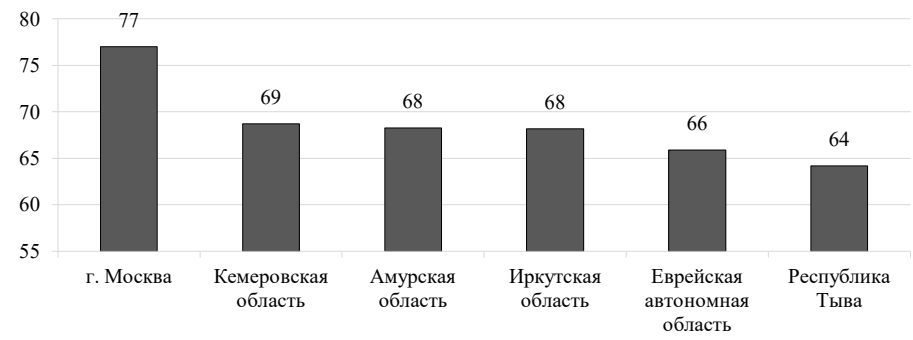

Pис. 3. Ожидаемая продолжительность жизни по отдельным регионам РФ на начало 2017 г., лет

Если в Республике Ингушетия ожидаемая продолжительность жизни в 2017 г. составила 81 год; то в Кемеровской, Иркутской и в Амурской областях - на 12-13 лет меньше, в Еврейской $\mathrm{AO}$ на 15, а в Республике Тыва - на 17 лет меньше. В Республике Тыва, Еврейской $\mathrm{AO}$ и в Чукотском автономном округе в среднем ни один мужчина не доживает до установленного в настоящее время пенсионного возраста - 60 лет. До 65 лет не будут доживать мужчины уже в 37 регионах России, или почти в 44\% субъектах РФ (табл. 1).

\section{Таблица 1. Группировка регионов РФ с ожидаемой продолжитель- ностью жизни мужчин ниже планируемого пенсионного возраста на начало 2017 г.}

\begin{tabular}{|l|c|c|}
\hline $\begin{array}{c}\text { Ожидаемая продолжитель- } \\
\text { ность жизни мужчин, лет }\end{array}$ & $\begin{array}{c}\text { Среднее отклонение от } \\
\text { принятого пенсионного } \\
\text { возраста (65 лет), лет }\end{array}$ & $\begin{array}{c}\text { Количество регионов с низ- } \\
\text { кой продолжительностью } \\
\text { жизни, ед. }\end{array}$ \\
\hline 64 & 1 & 17 \\
\hline 63 & 2 & 12 \\
\hline $61-62$ & $3-4$ & 5 \\
\hline $59-60$ & $5-6$ & 37 \\
\hline Итого & $\mathrm{x}$ & 43,5 \\
\hline $\begin{array}{l}\text { Доля от общего количества } \\
\text { регионов,\% }\end{array}$ & $\mathrm{x}$ & \\
\hline
\end{tabular}

Источник табл. 1-4: Расчеты автора по данным источника: Регионы России. Социально-экономические показатели. 2017: Стат. сб. / Росстат. М., 2017. 1402 c.

\footnotetext{
${ }^{6}$ Составлено автором по данным: Регионы России. Социально-экономические показатели. 2017: Стат. сб. / Росстат. М., 2017. 1402 с.
} 
Кроме того, установленный пенсионный возраст 90 лет назад большинство жителей страны считают одним из величайших социальных завоеваний СССР. По данным опросов, люди отмечают, что они откладывали многие дела «до пенсии», чтобы, пока есть силы, пожить «для себя, для своей семьи», поправить здоровье, заслуженно отдохнуть хотя бы несколько лет.

Судя по реальной продолжительности и условиям жизни, многим и сегодня не удается дотянуть до пенсионного возраста или «спокойно пожить на пенсии». А сдвиг возрастной планки на 5 лет поставит в такое положение еще большее количество людей.

Это может стать сложной социальной проблемой, возникновение которой недопустимо в современных непростых для страны социально-экономических условиях.

Bblвод: увеличение пенсионного возраста в настоящее время нельзя считать целесообразным для значительного количества населения РФ.

2. Аргумент "за»: в современном мире с учетом развития медиџины границы пожилого возраста сдвинулись, и, следовательно, рамки трудоспособного возраста расширились.

\section{Результаты анализа}

Данное утверждение, к сожалению, не отвечает фактам реальной жизни. Доступность медицины далеко не везде соответствует необходимой. За последние 10 лет обеспеченность больничными койками в среднем по России снизилась на $36 \%$ при росте заболеваемости за тот же период на $6 \%$. Причем, если в среднем по стране на каждую тысячу жителей ежегодно впервые выявляется около 800 заболеваний, то почти в $25 \%$ регионов РФ - от 913 до 1,4 тыс. заболеваний с тенденцией к росту (табл. 2).

Особенно напряженная ситуация в сельской местности, где в результате «оптимизации» медицинских услуг закрыты фельдшерско-акушерские пункты и больницы, имеются недостаток медицинских кадров, транспортные и другие проблемы [Казанцева, Тагаева, 2018. С. 90-104]. В городах также наблюдаются проблемы с получением медицинской помощи - невозможность попасть на прием к врачу в момент заболевания, отсутствие необходимых лекарств, недостаток денежных средств для их приобретения, так как значительная доля населения имеет доходы ниже прожиточного минимума (табл. 3), и другое [Калугина, 2017. C. 52-56]. 
Таблица 2. Заболеваемость на 1000 человек населения в некоторых регионах РФ в 2005-2016 гг. (зарегистрировано заболеваний у пациентов с диагнозом, установленным впервые в жизни)

\begin{tabular}{|l|c|c|c|c|}
\hline \multirow{2}{*}{ Регион } & \multicolumn{4}{|c|}{ Зарегистрировано заболеваний на 1000 человек } \\
\cline { 2 - 5 } & $\mathbf{2 0 0 5}$ & $\mathbf{2 0 1 4}$ & $\mathbf{2 0 1 5}$ & $\mathbf{2 0 1 6}$ \\
\hline РФ & 743,7 & 787,1 & 778,2 & 785,3 \\
\hline Владимирская область & 877,6 & 913,9 & 937,7 & 944,2 \\
\hline Орловская область & 828,5 & 932,3 & 970,2 & 951,9 \\
\hline Республика Карелия & 1027,1 & 1113,8 & 1114,3 & 1126,2 \\
\hline Республика Коми & 960,4 & 1054,8 & 1072,0 & 1121,2 \\
\hline Архангельская область & 926,6 & 1007,5 & 1030,9 & 1016,4 \\
\hline Ненецкий АО & 1632,4 & 1436,8 & 1421,4 & 1380,7 \\
\hline г. Санкт-Петербург & 724,9 & 877,7 & 931,5 & 1009,6 \\
\hline Удмуртская Республика & 893,7 & 945,4 & 968,2 & 991,0 \\
\hline Чувашская Республика & 858,6 & 1019,0 & 983,4 & 934,2 \\
\hline Самарская область & 855,3 & 1016,0 & 1033,7 & 975,7 \\
\hline Курганская область & 813,3 & 914,8 & 925,2 & 970,4 \\
\hline Ямало-Ненецкий АО & 1178,0 & 1132,1 & 1096,9 & 1180,4 \\
\hline Алтайский край & 987,2 & 1082,3 & 1096,5 & 1130,3 \\
\hline Иркутская область & 833,9 & 955,4 & 952,2 & 1000,6 \\
\hline Республика Саха (Якутия) & 881,7 & 1098,1 & 1026,6 & 1043,8 \\
\hline Чукотский АО & 1189,1 & 1025,2 & 1076,3 & 1289,4 \\
\hline
\end{tabular}

Таблица З. Группировка регионов РФ с долей населения, имеющего денежные доходы ниже прожиточного минимума, 2016 г., \%

\begin{tabular}{|c|c|}
\hline \multicolumn{1}{|c|}{$\begin{array}{c}\text { Доля населения с денежными доходами } \\
\text { ниже прожиточного минимума }\end{array}$} & $\begin{array}{c}\text { Доля регионов от общей } \\
\text { численности субъектов РФ }\end{array}$ \\
\hline $14-20$ & 50,0 \\
\hline $21-25$ & 6,1 \\
\hline $26-42$ & 6,0 \\
\hline $\begin{array}{l}\text { Всего регионов, где более 14\% жителей имеют доходы ниже } \\
\text { прожиточного минимума }\end{array}$ & 62,1 \\
\hline
\end{tabular}

Примечание: по данным Росстата, в среднем по России доля населения, денежные доходы которых ниже прожиточного минимума, составляет 13,4\%.

Отметим, что возраст наступления физиологических изменений организма человека остался прежним. Снижение количества эстрогенов у подавляющего большинства женщин начинается в 45-50 лет. К 55 годам эстрогены сокращаются до минимума у всех женщин, что приводит к существенному снижению работоспособности, ухудшению памяти, остеопорозу, развитию 
атеросклероза, других характерных возрастных заболеваний [Сухих, Сметник и др., 2016]. У мужчин тоже возникают подобные изменения 7 . В целом, по данным ВОЗ, после 60 лет у 90 \% людей возникают с той или иной степенью выраженности признаки деменции (нарушение памяти, раздражительность, элементы агрессивного поведения и др. $)^{8}$.

Именно поэтому в советское время был установлен пенсионный возраст 55 лет для женщин и 60 лет для мужчин.

Bblвод: ни действующая система здравоохранения, ни генетические предпосылки не способствуют увеличению продолжительности активной трудоспособности всего населения страны.

3. Аргумент «за»: граждане с 60 до 64 лет - это достаточно активные в экономическом и социальном плане люди. Уже сейчас 1/3 людей пенсионного возраста продолжают работать, причем в первые пять лет после назначения пенсии данный показатель гораздо выше. Это лишнее подтверждение того, что фактически трудоспособный возраст в настоящее время выме общеустановленного пенсионного. С учетом этого обстоятельства возможно повысить пенсионный возраст.

\section{Результаты анализа}

Активность граждан пенсионного возраста в настоящее время объясняется прежде всего и главным образом низким уровнем пенсионного обеспечения [Кузнецова, 2018], который напрямую зависит от размеров оплаты труда (табл. 4).

Таблица 4. Доля регионов РФ с минимальным уровнем средней заработной платы отдельных категорий работников

\begin{tabular}{|l|c|c|}
\hline \multicolumn{1}{|c|}{ Категория } & $\begin{array}{c}\text { Среднерегиональная } \\
\text { величина заработной } \\
\text { платы, тыс. руб. }\end{array}$ & $\begin{array}{c}\text { Доля регионов, \% } \\
\text { от общего количе- } \\
\text { ства субъектов РФ }\end{array}$ \\
\hline Социальные работники & $11-14$ & 29,3 \\
\hline Педагогические работники учреждений: & & \\
\hline дошкольных & $14-19$ & 30,5 \\
\hline общего образования & $18-21$ & 19,5 \\
\hline
\end{tabular}

\footnotetext{
${ }^{7}$ Ученые: деменция и инсульт грозят каждой второй женщине / Наука // Газета. py [Эл. ресурс]. URL: https://www.gazeta.ru/science/news/2018/10/01/n_12109891. shtml (дата обращения: 02.10.2018).

${ }^{8}$ Мясников А.Л. Гипертоникам грозит болезнь Альцгеймера: кто ещё в группе риска, признаки болезни Альцгеймера и как замедлить процесс развития болезни на ранней стадии. 21.09.2018// Официальная страница ТВ-передачи «О самом главном» [Эл. peсурс]. URL: https://vk.com/life.and.health (дата обращения: 21.09.2018)
} 
Окончание табл. 4

\begin{tabular}{|l|c|c|}
\hline \multicolumn{1}{|c|}{ Категория } & $\begin{array}{c}\text { Среднерегиональная } \\
\text { величина заработной } \\
\text { платы, тыс. руб. }\end{array}$ & $\begin{array}{c}\text { Доля регионов, \% } \\
\text { от общего количе- } \\
\text { ства субъектов РФ }\end{array}$ \\
\hline дополнительного образования & $15-19$ & 23,2 \\
\hline $\begin{array}{l}\text { начального и средне-профессионального } \\
\text { образования, прочих социальных организаций }\end{array}$ & $17-20$ & 22,0 \\
\hline Медперсонал: & & \\
\hline средний & $16-20$ & 39,0 \\
\hline младший & $10-15$ & 57,3 \\
\hline Работники учреждений культуры & $11-16$ & 36,6 \\
\hline Научные сотрудники & $20-30$ & 23,2 \\
\hline
\end{tabular}

При существующем уровне заработной платы минимальный размер пенсий в ряде регионов России не превышает 7-10 тыс. руб. При оплате коммунальных услуг в размере 5-6 тыс. руб. и более у получателей таких пенсий просто не остается средств на существование. Социальные выплаты большинству из них не положены, так как прожиточный минимум для пенсионеров на 2018 г. установлен в размере 8583 руб. ${ }^{9}$ В 2019 г. планируется его поднять до 8846 руб..$^{10}$ Поэтому пенсионеры вынуждены идти работать, причем часто на такую же низкооплачиваемую работу. При этом работающим пенсионерам не индексируют пенсии, вынуждая их трудиться «до последнего», что никак не связано с уровнем их здоровья и желанием социальной активности.

Bblвoд: наличие работающих пенсионеров в стране не может быть основанием для продления пенсионного возраста.

4. Аргумент «за»: в настоящее время наблюдается растущиий дефицит на рынке труда, причем речь идет именно о квалифицированных рабочих и специалистах. Современный тип экономики (постиндустриальный) не подразумевает массовой занятости во вредных (опасных) условиях труда, приводящей $\kappa$ ранней утрате трудоспособности. Напротив, сегодняшний рынок труда, связанный со сферой услуг и интеллектуальной

\footnotetext{
${ }^{9}$ Об установлении величины прожиточного минимума на душу населения и по основным социально-демографическим группам населения в целом по Российской Федерации за II квартал 2018 года: Приказ Минтруда России от 24.08.2018 № 550н // КонсультантПлюс, 2018.

${ }^{10}$ Проект федерального закона № 556362-7 «О федеральном бюджете на 2019 год и на плановый период 2020 и 2021 годов» [Эл. ресурс]. URL: http://static.consultant.ru/ obj/file/doc/fz_011018-2.pdf (дата обращения: 02.10.2018).
} 
деятельностью, предполагает длительный период способности $\kappa$ труду.

\section{Результаты анализа}

Дефицит на рынке труда высококвалифицированных кадров действительно имеется. Однако его нельзя восполнить продлением пенсионного возраста, так как основная доля работников не относится к данной категории. Среди работающих в настоящее время 66,5\% имеют среднее либо среднеспециальное образование или совсем не имеют основного общего образования ${ }^{11}$.

Кроме того, в 2016 г. средний уровень занятости в стране лиц трудоспособного возраста составил лишь около 66\%, на селе $60 \%$. Из них официально обратились в службы занятости и встали на учет в качестве безработных только 4,1 млн человек, средний возраст которых около 36 лет, из них более $66 \%$ - это городское население. Среди безработных всего около 20\% - люди с высшим образованием, и более $\mathbf{8 0 \%}$ - со средним специальным и без специального образования.

Если допустить, учитывая потенциал увеличения трудоспособного населения за счет молодого поколения из расчета 2 млн чел. ежегодно, что в результате увеличения пенсионного возраста, 20,5 млн чел. не уйдут на пенсию, а останутся на своих рабочих местах, то минимум для 6 млн чел. (4 млн безработных и 2 млн молодых людей) потребуется создание дополнительных рабочих мест.

Если на организацию 1 рабочего места, по расчетам специалистов, требуется от 100 до 200 тыс. долл., ${ }^{12}$ или в современных ценах - от 6 до 12 млн руб., то примерная сумма затрат на создание новых вакансий потребует ежегодно от 12 до 36 трлн руб.

Необходимо также учитывать объективную неспособность многих людей в пожилом возрасте выполнять прежнюю работу и весьма вероятную потребность в их переобучении, трудоустройстве, выплате пособий по безработице. На это тоже потребуются дополнительные средства. Работающие пожилые

\footnotetext{
${ }^{11}$ Регионы России. Социально-экономические показатели. 2017: Стат. сб. / Росстат. M., 2017. 1402 c.

${ }^{12}$ Вербицкая H. 25 млн рабочих мест обойдутся слишком дорого // Регионы России: Регионы Онлайн [Эл. ресурc]. URL: https://www.gosrf.ru/news/6667/ (дата обращения: 02.10.2018).
} 
люди чаще болеют. Значит, нужно предусмотреть расходы на их лечение и на оплату «больничных».

Необходимо также учитывать, что у пожилых людей на порядок ниже производительность труда (зачастую до пяти и более раз), выше риски производственного брака, некачественного выполнения особенно сложных заданий. Поэтому нельзя рассчитывать, что они восполнят дефицит на рынке труда, причем именно квалифицированных рабочих мест.

Bывод: принудительное продление пенсионного возраста экономически не оправдано.

Решая проблему кадрового дефицита необходимо идти по пути реиндустриализации, автоматизации и роботизации производства и сферы услуг, что позволит замещать сотрудников, в том числе на требующих высокой квалификации рабочих местах, тем самым существенно повышая производительность труда. Например, в докладе «Будущее рабочих мест 2018» на Всемирном экономическом форуме (WEF) Евразийским институтом конкурентоспособности и консалтинговой компанией Strategy Partners показано, что около $1 / 4$ рабочих мест может быть автоматизировано более чем на 70\%. В результате в России в 2020-2025 гг. можно будет сократить до трети персонала во всех секторах экономики ${ }^{13}$.

5. Аргумент «за»: наблюдается постоянный рост числа пенсионеров на фоне сокращения количества лиц, за котоpых уплачиваются страховые взносы. Если в 1970 г. было 3,7 работающих на одного пенсионера, то к 2019 г. этот показатель составит примерно два человека и дальще будет уменьшаться - убыль трудоспособного населения ежегодно составляет 0,4 млн человек, а количество пенсионеров растет. В этой связи собираемых взносов не хватает для обеспечения достойной пенсии.

\section{Результаты анализа}

Приведенные в качестве аргументов расчеты не совсем корректны, так как идет убыль не только трудоспособного населения, но и пенсионеров, в то время как численность молодежи до 15 лет

\footnotetext{
${ }^{13}$ Будущее наступает: когда роботы вытеснят людей. Треть россиян может остаться без работы через два года // Газета.ру [Эл. ресурс]. URL: https://www.gazeta.ru/ business/2018/09/18/11973649.shtml (дата обращения: 27.09.2018).
} 
растет (рис. 4) $)^{14}$. При этом соотношение между количеством трудоспособного населения и числом пенсионеров мало изменилось за последние 12 лет, оставаясь в пределах 3,1-2,3 человек на 1 пенсионера ${ }^{15}$.

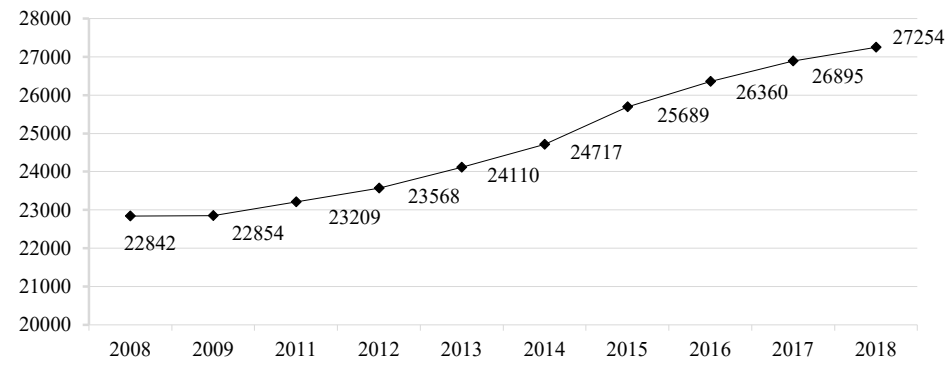

Puc. 4. Динамика численности населения России моложе трудоспособного возраста в 2008-2018 гг., тыс. чел.

С учетом того, что не все мужчины доживают до пенсионного возраста, соотношение мужчин в возрасте 60 лет и старше и трудоспособного возраста (15-59 лет) на 01.01.2017 было 1: 4. То есть численность населения мужского пола в трудоспособном возрасте превысила численность мужчин-пенсионеров в четыре раза ${ }^{16}$. То, что не все из них являются плательщиками взносов в ПФР, не должно быть проблемой пенсионеров.

С аргументом о недостатке пенсионных взносов в ПФ нельзя полностью согласиться, так как, по официальным данным Минфина России, например, в 2016 г. доходы Пенсионного фонда составили 7731 млрд руб., расходы-7413 млрд руб. Профищит бюджета ПФ был 318 млрд руб.

Относительная экономия ПФ от увеличения пенсионного возраста, не учитывающая указанных выше расходов на проведение пенсионной реформы, составит около 3,5 трлн руб. в год. Однако дополнительные затраты, в том числе связанные

\footnotetext{
${ }^{14}$ Составлено автором по данным источника: Демография // Официальная статистика. Население [Эл. ресурс] / Федеральная служба госстатистики. URL: http://www. gks.ru/wps/wcm/connect/rosstat_main/rosstat/ru/statistics/population/demography/\# (дата обращения: 01.10.2018).

${ }^{15}$ Расчеты автора по данным: Регионы России. Социально-экономические показатели. 2017: Стат. сб. / Росстат. М., 2017. С. 47-50

${ }^{16}$ Расчеты автора по данным источника: Российский статистический ежегодник. 2017: Стат.сб./ Росстат. М., 2017. С. 88.
} 
с увеличением выплат пособий по безработице, созданием новых рабочих мест, организацией переобучения лиц пенсионного возраста, строительством детских садов (в связи с отсутствием свободного времени для внуков у бабушек и дедушек) $)^{17}$ и пр.; могут полностью нивелировать расчетную экономию от повышения пенсионного возраста.

Таким образом, получение экономического эффекта в результате увеличения пенсионного возраста чрезвычайно сомнительно.

Что касается снижения отчислений в Пенсионный фонд, то это в значительной степени связано с низким уровнем оплаты труда большинства работников, как было показано выше; а также с высокой налоговой нагрузкой на организации; с дисбалансом цен в экономике; ростом налога на добавленную стоимость, цен на энергоносители и тарифов на коммунальные услуги, с высокими ставками по кредитам и другими факторами, приводящими к убыточности и низкой рентабельности производства ${ }^{18}$. Все это влечет за собой снижение заработных плат и налоговых отчислений ${ }^{19}$, в том числе в Пенсионный фонд. В итоге получается замкнутый круг.

6. Аргумент «за»: повымение пенсионного возраста призвано обеспечить увеличение размеров пенсий. В противном случае рост числа пенсионеров и снижение количества трудоспособных лии создают высокий риск для пенсионной системы РФ, основанной на солидарных принщипах, заключающийся в невозможности обеспечения сочиально-приемлемого уровня пенсионного обеспечения.

${ }^{17}$ Примечание. В настоящее время в большинстве городских детских дошкольных образовательных учреждений отмечается наличие детей в группах выше установленных норм СанПиН (Санитарно-эпидемиологические правила и нормативы СанПиН 2.4.1.3049-13// КонсультантПлюс), и по официальным данным, на начало 2018 г. в РФ дефицит мест в детских дошкольных учреждениях превышает 1 млн.

18 1. Регионы России. Социально-экономические показатели. 2017: Стат. сб. / Росстат. М., 2017. 1402 c.

2. Российский статистический ежегодник. 2017: Стат.сб./ Росстат. М., 2017. 686 с.

${ }^{19}$ Раздел ХІ. Страховые взносы в РФ. Глава 34. Страховые взносы. Статья 426. Тарифы страховых взносов в 2017-2020 годах / Налоговый кодекс Российской Федерации (часть вторая) от 05.08.2000 № 117-ФЗ (ред. от 03.08.2018) // Законы, кодексы и нормативноправовые акты Российской Федерации [Эл. ресурс]. URL: http://legalacts.ru/kodeks/ NK-RF-chast-2/razdel-xi/glava-34/statja-426/ (дата обращения: 02.10.2018). 


\section{Результаты анализа}

Из приведенных аргументов напрашивается вывод: если существующие солидарные принципы пенсионного обеспечения не соответствуют социальным потребностям, значит, их надо изменить и не ограничиваться пенсионными отчислениями работающего населения.

Кроме отчислений в ПФ в размере $22 \%$ от всех выплат работникам, необходимо найти и установить другие источники бюджетных поступлений.

В частности, в результате снижения экспортных пошлин на сырую нефть только в июне-ноябре 2016 г. по сравнению с тем же периодом 2015 г. федеральный бюджет недополучил более 238 млрд руб. (из расчета 60 руб. за 1 долл.) ${ }^{20}$.

Нерациональные затраты бюджетных средств также ведут к потерям ресурсов, которые могли бы быть направлены в Пенсионный фонд. По данным Счетной палаты, в стране 9 тыс. незавершённых объектов с общим объемом «замороженных» федеральных средств на 2,5 трлн руб. ${ }^{21}$

Следующим чрезвычайно рискованным направлением в современных условиях введения антироссийских санкций является приобретение ценных бумаг и валюты США за счет средств госбюджета - к началу 2017 г. объем резервных активов (без монетарного золота) составил 317,6 млрд долл. США, или более 21,2 трлн руб. ${ }^{22}$

Можно было бы пересмотреть и участие России в некоторых международных организациях, не отвечающих интересам страны, но требующих серьезных бюджетных вливаний -

\footnotetext{
${ }^{20}$ Расчеты автора по данным:

1. Таможенно-тарифное регулирование / Минэкономразвития России [Эл. ресурс]. URL: http:/economy.gov.ru/minec/activity/sections/foreignEconomicActivity/regulation/ (дата обращения: 02.10.2018).

2. Мониторинг внешней торговли России / Сводный департамент макроэкономического прогнозирования. Департамент тарифного регулирования и анализа внешнеэкономической деятельности. М., январь 2017 г. С. 40.

${ }^{21}$ Счётная палата обнаружила большие резервы в федеральном бюджете // Парламентская газета [Эл. pecypc]. URL: https://yandex.ru/turbo?text=https\%3A\%2F\%2Fwww. pnp.ru\%2Feconomics $\% 2$ Fschyotnaya-palata-obnaruzhila-bolshie-rezervy-v-federalnombyudzhete.html\&promo=navbar\&utm_referrer=https $\% 3 \mathrm{~A} \% 2 \mathrm{~F} \% 2 \mathrm{Fzen} . \mathrm{yandex}$. com\%2F\%3Ffrom\%3Dsearchapp (дата обращения: 01.10.2018).

${ }^{22}$ Российский статистический ежегодник. 2017: Стат. сб./ Росстат. М., 2017. С. 663-664.
} 
до 400 млрд руб. ежегодно (Совет Европы: 2-3 млрд руб.; ВТО: 0,2-0,3 млрд руб. и т.д.).

Необходимо навести порядок с оплатой труда во всех компаниях, независимо от формы собственности, установив 10-12-кратную разницу в уровнях минимальной и максимальной зарплат (по опыту СССР). В нынешней практике разница в оплате труда топ-менеджеров и рядовых сотрудников может доходить до нескольких сот раз. Это ограничивает возможности развития производства, стимулирования высокопроизводительного труда работников низовых звеньев, порождает социальное неравенство.

Немалых затрат требует оплата труда сотрудников министерств и ведомств, в том числе и регионального уровня. В целях повышения материальной мотивации госслужащих в 2019 г. Минфином РФ предлагается направить на эти цели 143,6 млрд руб., в 2020 г. - 208,9 млрд руб. и в 2021 г. - 284,4 млрд руб..$^{23}$ У членов Госдумы зарплаты - в среднем около 400 тыс. руб. в месяц, то есть в 40-50 раз выше минимальной оплаты труда. С учетом затрат на оплату труда помощников депутатов и прочих расходов содержание Госдумы обходится бюджету в 15-20 млрд руб. ежегодно.

Дополнительные поступления в бюджет могут быть связаны с введением прогрессивного налога на доходы физических лиц (более 1 трлн руб.), а также изменением шкалы налога на прибыль юридических лиц - высокорентабельных компаний (нефтяных, газовых, железнодорожных и др.) с отменой для них фиксированных ставок налогов в абсолютных показателях.

Профицит бюджета РФ в 2019-2021 гг. планируется в размере 1-2 трлн руб. Часть средств можно было бы также направить в $\Pi \Phi^{24}$.

Могут быть задействованы и другие источники пополнения ПФР.

${ }^{23}$ Проект федерального закона №556362-7 «О федеральном бюджете на 2019 год и на плановый период 2020 и 2021 годов» [Эл. ресурс]. URL: http://static.consultant.ru/ obj/file/doc/fz_011018-2.pdf (дата обращения: 03.10.2018).

${ }^{24} \mathrm{O}$ внесении в Госдуму законопроекта о федеральном бюджете на 2019 год и на плановый период 2020 и 2021 годов / Правительство Российской Федерации [Эл. ресурс]. URL: http://government.ru/activities/selection/301/34139/ (дата обращения: 02.10.2018). 
Bblвoд: при задействовании указанных и иных резервов для формирования пенсионного фонда в ближайшие годы можно вполне обойтись без увеличения пенсионного возраста.

7. Аргумент «за»: пенсионная система должна соответствовать международным стандартам, а также принимать во внимание опыт по повышению нормативного пенсионного возраста рядом европейских государств и государствами, из числа бывших республик СССР, являющихся партнерами РФ в рамках ЕАЭС.

\section{Результаты анализа}

Ссылка на международный опыт установления пенсионного возраста некорректна в связи с существенными различиями в природно-климатических и экономических условиях стран, которые зачастую складываются не в пользу РФ. Если в странах ЕС средняя продолжительность жизни мужчин - 78 лет, а женщин - 83 года, то в России, соответственно, на 12 лет и на 7 лет меньше (рис. 5$)^{25}$.

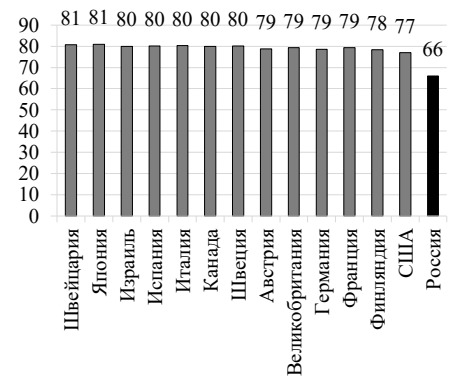

Мужчины

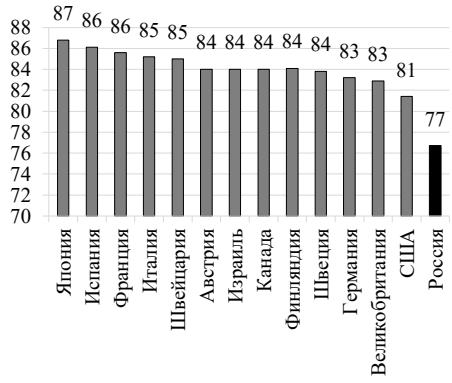

Женщины

Puc. 5. Ожидаемая продолжительность жизни мужчин и женщин при рождении, лет

В ряде бывших республик СССР, в том числе вошедших в ЕАЭС (Армения, Беларусь, Казахстан), продолжительность жизни также выше среднероссийской (рис. 6).

Ратифицированная Госдумой РФ Конвенция Международной организации труда о минимальных нормах социального обеспечения от 28 июня 1958 г. № 102, предусматривающая

\footnotetext{
${ }^{25}$ Россия и страны мира. 2016: Стат.сб./ Росстат. М., 2016. 379 с.; Россия и странычлены Европейского союза. 2017: Стат.сб./ Росстат. М., 2017. 264 с.
} 
выплату пенсий в размере 40\% от заработной платы, тоже не отвечает социально-экономическим условиям России из-за чрезвычайно низкой оплаты труда у большинства категорий работников (табл. 5). Пенсии в размере 20 тыс. руб. могут быть доступны только при оплате труда не ниже 50 тыс. руб. в месяц. В современных экономических условиях это недостижимо для подавляющего большинства работников $89 \%$ регионов России ${ }^{26}$.

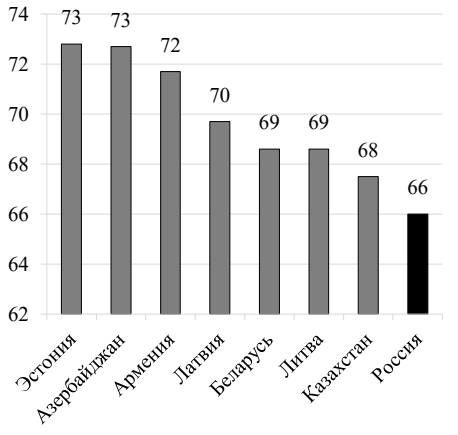

Мужчины
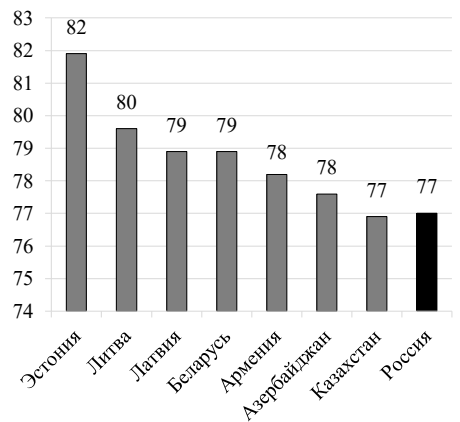

Женщины

Puc. 6. Ожидаемая продолжительность жизни мужчин и женщин при рождении в странах ближнего зарубежья, лет

Таблица 5. Размер пенсий в регионах РФ с минимальным уровнем средней заработной платы отдельных категорий работников

\begin{tabular}{|l|c|c|c|c|}
\hline \multicolumn{1}{|c|}{ Категория } & $\begin{array}{c}\text { Среднере- } \\
\text { гиональная } \\
\text { величина зара- } \\
\text { ботной платы, } \\
\text { тыс. руб. }\end{array}$ & $\begin{array}{c}\text { Размер } \\
\text { пенсии, тыс. } \\
\text { руб. (40\% } \\
\text { от размера } \\
\text { зарплаты) }\end{array}$ & $\begin{array}{c}\text { Доля } \\
\text { коммуналь- } \\
\text { ных услуг } \\
\text { в пенсионных } \\
\text { доходах,\% }\end{array}$ & $\begin{array}{c}\text { Доля } \\
\text { регионов,\% } \\
\text { от общего } \\
\text { количества } \\
\text { субъектов РФ }\end{array}$ \\
\hline Социальные работники & $11-14$ & $4-6$ & 100 & 29,3 \\
\hline $\begin{array}{l}\text { Педагогические работни- } \\
\text { ки учреждений: }\end{array}$ & $14-19$ & $6-8$ & $83-100$ & 30,5 \\
\hline $\begin{array}{l}\text { дошкольных } \\
\text { общего образования }\end{array}$ & $18-21$ & $7-8$ & $70-100$ & 19,5 \\
\hline $\begin{array}{l}\text { дополнительного об- } \\
\text { разования }\end{array}$ & $15-19$ & $6-8$ & $80-100$ & 23,2 \\
\hline
\end{tabular}

${ }^{26}$ Расчеты автора по данным: Регионы России. Социально-экономические показатели. 2017: Стат. сб. / Росстат. М., 2017. 1402 с. и др. источникам (официальный сайт, штатное расписание, раскрытие информации и т.п.). 
Окончание табл. 5

\begin{tabular}{|c|c|c|c|c|}
\hline Категория & $\begin{array}{c}\text { Среднере- } \\
\text { гиональная } \\
\text { величина зара- } \\
\text { ботной платы, } \\
\text { тыс. руб. }\end{array}$ & $\begin{array}{c}\text { Размер } \\
\text { пенсии, тыс. } \\
\text { руб. (40\% } \\
\text { от размера } \\
\text { зарплаты) }\end{array}$ & $\begin{array}{c}\text { Доля } \\
\text { коммуналь- } \\
\text { ных услуг } \\
\text { в пенсионных } \\
\text { доходах, \% }\end{array}$ & $\begin{array}{c}\text { Доля } \\
\text { регионов, \% } \\
\text { от общего } \\
\text { количества } \\
\text { субъектов РФ }\end{array}$ \\
\hline $\begin{array}{l}\text { начального, средне- } \\
\text { профессионального } \\
\text { образования, прочих } \\
\text { соц. организаций }\end{array}$ & $17-20$ & $7-8$ & $70-100$ & 22,0 \\
\hline \multicolumn{5}{|l|}{ Медперсонал: } \\
\hline средний & $16-20$ & $6-8$ & $78-100$ & 39,0 \\
\hline младший & $10-15$ & $4-6$ & 100 & 57,3 \\
\hline $\begin{array}{l}\text { Работники учреждений } \\
\text { культуры }\end{array}$ & $11-16$ & $4-6$ & $90-100$ & 36,6 \\
\hline Научные сотрудники & $20-30$ & $8-12$ & $63-100$ & 23,2 \\
\hline Депутаты Госдумы & 400 & 160 & $x$ & $x$ \\
\hline $\begin{array}{l}\text { Рядовые госслужащие } \\
\text { федерального уровня }\end{array}$ & $120-200$ & $48-80$ & $x$ & $x$ \\
\hline Министр финансов & 2000 & 800 & $x$ & $\mathrm{x}$ \\
\hline Министры РФ & $600-1500$ & $240-600$ & $\mathrm{x}$ & $\mathrm{x}$ \\
\hline \multicolumn{5}{|l|}{ OАО «Газпром»: } \\
\hline топ-менеджмент & 5-12 млн & $2-5$ млн & $\mathrm{x}$ & $\mathrm{x}$ \\
\hline рядовой сотрудник & $60-80$ & $24-32$ & $x$ & $x$ \\
\hline
\end{tabular}

Bblвод: достойный уровень пенсии останется недостижимой мечтой и в будущем для абсолютного большинства населения страны.

8. Аргумент «за»: эта мера будет рассчитана на длительный переходный период - с 2019 г. по 2034 г.

\section{Результаты анализа}

Длительный переходный период не сыграет положительную роль в уровне пенсионного обеспечения, так как негативные тенденции в экономике сохраняются, как и в предыдущие 15 лет: продолжаются рост цен и тарифов, инфляция и др. Если значительная часть населения еще 1-5 лет не будет получать дополнительные доходы в виде пенсионных выплат, социальная обстановка только ухудшится, можно ожидать роста бедности и безработицы, нарастания других негативных процессов.

Таким образом, пенсионная реформа обнажает не только сложившуюся несправедливость в оплате труда и доходах населения, рост бедности [Крюков, 2018. С. 3-6], но и нарушает 
консолидацию общества, что очень опасно в нынешних сложных социально-экономических и международных условиях.

Кроме того, несогласие народа с ущемлением своих прав вызывает обострение недоверия к власти. Об этом свидетельствует резкое изменение настроения в обществе, непрекращающиеся и после принятия законопроекта митинги и демонстрации против повышения пенсионного возраста, возникшие стихийно и под руководством профсоюзов, общественных организаций и политических партий сразу же после принятия Госудумой проекта пенсионной реформы ещё в первом чтении.

Общий вывод. Результаты проведенного исследования показывают, что планируемая к реализации с 2019 г. пенсионная реформа не позволит достичь ожидаемых положительных результатов. Более того, ведет к отрицательному экономическому и социальному эффекту.

Поскольку страна сможет успешно развиваться только при полной консолидации руководства и общества, в связи с указанным необходимо отложить реализацию пенсионной реформы и провести целенаправленную подготовительную работу. В частности, требуется:

- фактически повысить уровень и качество здравоохранения и социального обслуживания населения на всей территории РФ;

- изменить принципы формирования Пенсионного фонда с солидарного на нормативный с учетом потребностей для обеспечения качественной жизни всему населению страны;

- увеличить реальную заработную плату в целях обеспечения адекватного размера пенсии (из расчета рекомендуемых международными требованиями 40\% от заработной платы);

- сформировать действенный механизм регулирования цен и тарифов, препятствующих снижению реальных доходов населения;

- осуществить реиндустриализацию экономики на основе автоматизации и роботизации производственных процессов;

- повысить уровень квалификации и подготовки населения к освоению новой техники и технологий;

- сбалансировать наличие рабочих мест и количество населения в трудоспособном возрасте; 
- подойти дифференцированно к установлению пенсионного возраста по регионам страны;

- другие меры.

Только после проведения указанных мероприятий можно при необходимости вернуться к вопросу о реализации принятого федерального закона № 350-ФЗ и повышении пенсионного возраста в России.

\section{Литература}

Казанцева Л.К., Тагаева Т.О. Общественное здоровье и проблемы здра-воохранения в России и регионах // Экономика Сибири в условиях глобаль-ных вызовов XXI века: сборник статей в 6 т. Т. 1: Социальные детерминанты развития Сибири в пространстве и во времени / Под ред. С.В. Коржук. Новосибирск: ИЭОПП СО РАН, 2018. 200 с.

Калугина З.И. Институциональное обеспечение развития человеческого капитала // Трансформация человеческого потенциала в контексте столетия/ Под общ. ред. проф. 3. Х. Саралиевой: в 2 т. Т 1. Н. Новгород: Изд-во НИСОЦ, 2017. 644 c.

Крюков В. Многоликая бедность // ЭКО. 2018. № 3. С. 3-6.

Кузнецова П. Недоходная бедность пожилых // ЭКО. 2018. № 3. С. 27-43.

Менопауза и климактерическое состояние у женщин. Клинические рекомендации / Сухих Г.Т., Сметник В.П. и др. // Российское общество акушеровгинекологов, Российская ассоциация по менопаузе Научный центр акушер-ства, гинекологии и перинатологии им. В.И. Кулакова МЗ РФ, 2016. URL: https:// medi.ru/klinicheskie-rekomendatsii/menopauza-i-klimaktericheskoe-sostoyanie-uzhenschiny_14063/(дата обращения: 02.10.2018).

Статья поступила 04.10.2018.

\section{Summary}

Shchetinina I.V., Institute of Economics and Industrial Production Organization, SB RAS, Novosibirsk

\section{Increasing the Retirement Age: Points for and Against}

The article provides an argument the need for raising the retirement age and an analysis of the actual socio-economic situation of the Russian population, in-dicating the country's unpreparedness for reform. The actual life expectancy of the population of the Russian Federation does not match the expected, as well as the duration and standard of living of the population of developed countries. The incidence of residents of many regions of Russia is growing morbidity. The level of actual labor remuneration and, accordingly, the potential amount of pensions not lower than $40 \%$ of the salary according to international requirements will not allow for ensuring the necessary quality of life for pensioners. The extension of the retirement age will not fill the lack of qualified personnel in the economy. The ratio of working-age population and pensioners is relatively stable. The neces-sary expenses for the implementation of pension reform may exceed the budget savings from raising the 
retirement age. It is proposed to introduce a deferral of the entry into force of the adopted law on pension reform and to carry out pur-poseful preparatory work in the system of health care, pension system, economic regulation of prices and tariffs, in other areas. This will allow, when the economy and society will be ready, to return to the question of the need to raise the retire-ment age.

Population; life expectancy; mortality; working and retirement age; unemployed; employment; income; pension system

\section{References}

Kazantseva L.K., Tagayeva T.O. (2018). Obshchestvennoye zdorov'ye i problemy zdravookhraneniya v Rossii i regionakh [Social health and Problems Health public in Russia and the Regions]. In: Ekonomika Sibiri v usloviyakh glob-al'nykh vyzovov XXI veka: Vol. 1: Sotsial'nyye determinanty razvitiya Sibiri v pros-transtve $i$ vo vremeni. Novosibirsk: IEOPP SO RAN Publ., 200 p. (In Russ.).

Kalugina Z.I. (2017). Institutsional'noye obespecheniye razvitiya chelovecheskogo kapitala [Institutional provision of the development of human capital]. In: Transformatsiya chelovecheskogo potentsiala $v$ kontekste stoletiya [Transfor-mation of human potential in the context of the century]. Vol. 1. N. Novgorod: Izd-vo NISOC Publ., 644 p. (In Russ.).

Kryukov V. (2018). Mnogolikaya bednost'. ECO. [ECO]. Vol. 48. No. 3. Pp. 3-6. (In Russ.).

Kuznetsova P. (2018). Nedokhodnaya bednost' pozhilykh. ECO. [ECO]. Vol. 48. No. 3. Pp. 27-43. (In Russ.).

Menopauza i klimaktericheskoye sostoyaniye u zhenshchin. Klinicheskiye reko-mendatsii (2016). [Menopause and climacteric condition in women. Clinical recom-mendations]. Developers: Sukhikh G.T., Smetnik V.P. i dr. Rossiyskoye obshchestvo akusherov-ginekologov, Rossiyskaya assotsiatsiya po menopauze Nauchnyy tsentr akusherstva, ginekologii i perinatologii im. V.I. Kulakova MZ RF. (In Russ.). Available at: https://medi.ru/klinicheskie-rekomendatsii/menopauza-iklimaktericheskoe-sostoyanie-u-zhenschiny_14063/(accessed 02.10.2018). 